\title{
ANALISIS DEBIT PUNCAK PADA DAS AIR MANNA BAGIAN HILIR MENGGUNAKAN PENDEKATAN METODE HIDROGRAF SATUAN SINTETIS (HSS) SNYDER DAN HEC-RAS 5.0.7M.
}

\author{
Hafidz Ramadhan ${ }^{1}$ Khairul Amri $^{2}$ Muhammad Fauzi $^{3}$ \\ ${ }^{1,2,3}$ Teknik Sipil Universitas Bengkulu \\ khairulftunib@yahoo.com
}

\begin{abstract}
Floods is a disaster which is one of the causes of failure of watershed managemen. High rainfall is also a factor in flooding. As a result the river cross section is not able to accommodate the flow of water and cause the river to overflow. This research was conducted to determine the amount of peak discharge Sub-DAS Downstream Manna Water and identify areas prone to flooding. This study uses a synthetic unit hydrograph (HSS) Snyder and HEC-RAS 5.0.7. Hydrological analysis results obtained from the peak discharge at Sub-DAS Rindu Hati using HSS Snyder for a return period of 2, 5, 10, 25, 50 and 100 yearsthat is $743,627 \mathrm{~m}^{3} / \mathrm{sec}, 839,491 \mathrm{~m}^{3} / \mathrm{sec}, 897,761 \mathrm{~m}^{3} / \mathrm{sec}, 962,599 \mathrm{~m}^{3} / \mathrm{sec}, 1008,717$ $\mathrm{m}^{3} / \mathrm{sec}$, and $1052,800 \mathrm{~m}^{3} / \mathrm{sec}$ with a peak time of 5,915 hours. After analysis using software HEC-RAS 5.0.7, DAS Air Manna no longer able to accommodate flow rates occur.
\end{abstract}

Keywords: Rainfall, Peak Discharge, HEC-RAS 5.0.7, Synthetic Unit Hydrograph, Snyder Return Period.

\begin{abstract}
ABSTRAK
Banjir adalah bencana yang salah satu penyebabnya terjadi akibat kegagalan pengelolaan DAS. Curah hujan yang tinggi juga menjadi faktor terjadinya banjir Akibatnya penampang sungai tidak mampu menampung aliran air dan mengakibatkan sungai meluap. Penelitian ini dilakukan adalah untuk mengetahui besarnya debit puncak di Sub-DAS Air Manna Bagian Hilir dan mengidentifikasi daerah rawan banjir. Penelitian ini dilakukan memakai metode hidrograf satuan sintetis (HSS) Snyder dan HEC-RAS 5.0.7. Dari hasil analisis hidrologi diperoleh debit puncak pada di Sub-DAS Air Manna Bagian Hilir menggunakan metode (HSS) snyder untuk periode ulang 2, 5, 10, 25, 50 dan 100 tahun yaitu 743,627 $\mathrm{m}^{3} /$ detik, $839,491 \mathrm{~m}^{3} /$ detik, $897,761 \mathrm{~m}^{3} /$ detik , $962,599 \mathrm{~m}^{3} /$ detik , 1008,717 $\mathrm{m}^{3} /$ detik, dan $1052,800 \mathrm{~m}^{3} /$ detik dengan waktu puncak sebesar 5,915 jam. Setelah dilakukan analisis menggunakan software HEC-RAS 5.0.7, di Sub-DAS Air Manna sudah tidak mampu lagi menampung debit aliran yang terjadi.
\end{abstract}

Kata kunci: Curah Hujan, Debit Puncak, HEC-RAS 5.0.7, Hidrograf Satuan Sintetik, Snyder Periode Ulang. 


\section{PENDAHULUAN}

\subsection{Latar belakang}

Daerah aliran sungai (DAS) adalah suatu wilayah yang dibatasi oleh punggung-punggung bukit yang menampung air hujan dan mengalirkannya melalui saluran air, dan kemudian berkumpul menuju suatu muara sungai, laut, danau atau waduk. DAS Air Manna merupakan DAS lintas Provinsi dengan luas sekitar 72.054,7 ha. Wilayah DAS ini membentang mulai daerah hulu di Kabupaten Lahat Provinsi Sumatera Selatan sampai di daerah hilir di Kabupaten Bengkulu Selatan Provinsi Bengkulu. (BPDAS Ketahun, 2016).

Permasalahan banjir menunjukkan perlu diadakan penelitian analisis debit puncak pada DAS Air Manna dengan menggunakan pendekatan metode Hidrograf Satuan Sintetis (HSS). Hidrograf aliran adalah bagian yang sangat penting untuk mengatasi masalah-masalah yang berkaitan dengan banjir dan ketersediaan air karena hidrograf aliran dapat menggambarkan suatu distribusi waktu dari aliran sungai dan dapat menentukan bentuk daerah aliran sungai (Junia dkk, 2015). Peneliti menggunakan Hidrograf Satuan Sintetis (HSS) Snyder kemudian dilakukan pemodelan banjir dengan mengunakan software Hydrologic Engineering Center's - River Analysis System (HEC-RAS) Versi 5.0.7.

HEC-RAS merupakan software pemodelan mengenai sungai. Peneliti lain yang menggunakan software ini seperti Irawan, E. S. (2017) menggunakan HEC$R A S$ versi 4.0 dan Kurniawan, O. (2019) menggunakan HEC-RAS versi 5.0.7. Oleh karena itu peneliti menggunakan $H E C-R A S$ versi 5.0.7. Hasil dari penelitian ini dapat membantu dalam melakukan evakuasi untuk mengurangi korban jiwa dan kerugian akibat bencana banjir serta diharapkan menjadi acuan dalam perbaikan (rekonstruksi) penampang sungai yang kemungkinan terjadi banjir.

\section{TINJAUAN PUSTAKA}

\subsection{Hidrologi}

Hidrologi adalah ilmu yang berkaitan dengan air. Menurut (Achmad, 2011). Hidrologi Dewasa ini merupakan ilmu yang penting dalam perkembangan. Studi hidrologi meliputi berbagai bentuk air serta menyangkut perubahanperubahannya, antara lain dalam keadaan cair, padat, gas, dalam atmosfer, di atas dan di bawah permukaan tanah, distribusinya, penyebarannya, gerakannya dan lain sebagainya. Siklus hidrologi dapat dilihat pada Gambar 2.1.

\subsection{Daerah Aliran Sungai (DAS)}

Daerah Aliran Sungai biasanya dibagi menjadi daerah hulu, tengah dan hilir. Daerah hulu DAS ciri-cirinya sebagai berikut: mempunyai kerapatan 


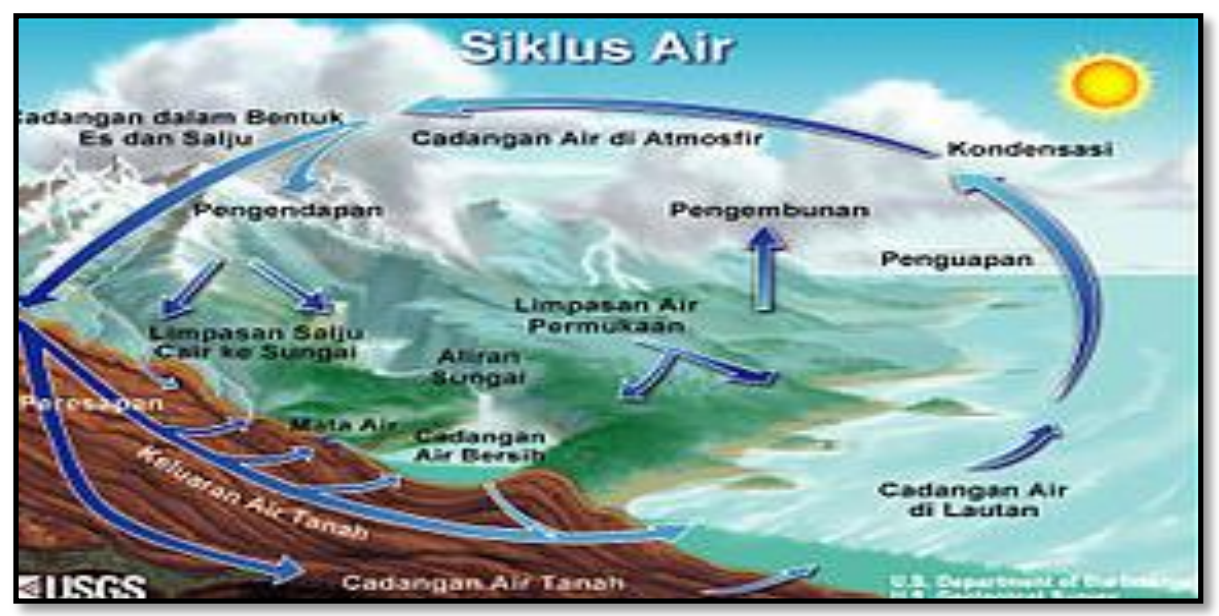

Gambar 2.1. Siklus Hidrologi

drainase lebih tinggi, merupakan daerah dengan kemiringan lereng besar (lebih besar dari 15\%), bukan merupakan daerah banjir, dan pengaturan pemakaian air ditentukan oleh pola drainase. Sementara daerah hilir DAS dicirikan oleh hal-hal sebagai berikut: merupakan derah pemanfaatan, kerapatan drainase lebih kecil, merupakan daerah dengan kemiringan lereng kecil sampai dengan sangat kecil (kurang dari 8\%), pada beberapa tempat merupakan daerah banjir (genangan), dan pengaturan pemakaian air ditentukan oleh bangunan irigasi. Daerah aliran sungai bagian tengah merupakan daerah transisi dari kedua karakteristik biogeofisik DAS yang berbeda (asdak, 2014).

\subsection{Banjir}

Berkembangnya peradaban manusia telah banyak mempengaruhi pengelolaan dan penanggulangan bencana. Dalam kasus banjir zaman Nabi Nuh, misalnya, dapat dipelajari tentang pentingnya peringatan (warning), kesiapsiagaan (preparedness), dan mitigasi.

Banjir paling sering terjadi pada musim penghujan, namun hujan tidak selalu menjadi faktor utama penyebab banjir. Menurut Nugroho (2014) ada 5 faktor penting terjadinya banjir di Indonesia yaitu Curah hujan, Karakteristik Daerah Aliran Sungai (DAS), Kemampuan alur sungai mengalirkan air banjir, Perubahan tata guna lahan di DAS, Pengelolaan sungai meliputi tata wilayah, pembangunan sarana-prasarananya hingga tata pengaturannya. Salah satu contoh pengendalian banjir yaitu melakukan normalisasi sungai. Normalisasi sungai adalah kegiatan yang bertujuan untuk melewatkan debit banjir rencana ( $\left.Q_{\text {rencana }}\right)$ secara aman dengan jalan mengecek kapasitas sungai dan melakukan pelurusan alur sungai yang disertai dengan perkuatan tebing dan stabilisasi dasar sungai, sehingga tidak terjadi limpasan/luapan. Debit banjir rencana merupakan debit rencana di sungai atau di saluran alamiah dengan periode ulang tertentu yang dapat dialirkan tanpa membahayakan lingkungan sekitar dan diperoleh dari analisis data hidrologi (Retnowati dkk, 2015). 


\subsection{Analisa Hidrologi}

\subsubsection{Perhitungan Debit}

Menurut Anonim II (2009), debit air (water discharge) adalah volume air yang mengalir melalui suatu penampang melintang sungai per satuan waktu, dalam satuan $\mathrm{m}^{3} / \mathrm{detik}$. Adapun perhitungan debit berdasarkan kondisi steady flow seperti berikut:

$$
Q=A x V
$$

dimana:

$Q=$ Debit air $\left(\mathrm{m}^{3} / \mathrm{dt}\right)$

$V=$ Kecepatan aliran $(\mathrm{m} / \mathrm{dt})$

$A=$ Luas penampang basah $\left(\mathrm{m}^{2}\right)$

\subsubsection{Curah Hujan}

Analisis curah hujan menurut Wigati dkk (2016) terdiri dari :

a. Uji Konsistensi Data

Uji konsistensi data yaitu dimana data yang terukur dan dihitung adalah data sesuai dengan fenomena saat hujan itu terjadi. Metode yang digunakan untuk mengoreksi data dengan cara Double Mass Curve atau Kurva Massa Ganda yang menggambarkan grafik hubungan antara curah hujan kumulatif stasiun yang diuji dengan curah hujan kumulatif stasiun disekitarnya.

b. Hujan Kawasan (DAS)

Curah hujan yang diperlukan untuk penyusunan suatu rancangan pemanfaatan air dan rancangan pengendalian banjir adalah curah hujan rata-rata di seluruh daerah yang bersangkutan. Curah hujan ini disebut curah hujan wilayah atau daerah dan dinyatakan dalam $\mathrm{mm}$. Data untuk perhitungan curah hujan rata-rata maksimum dari beberapa stasiun menggunakan cara aljabar.

\subsubsection{Distribusi Curah Hujan Rata-Rata Wilayah}

Perhitungan curah hujan rata-rata wilayah aliran sungai dapat dilakukan dengan menggunakan tiga yaitu metode rata-rata aritmatik (aljabar), metode Poligon Thiessen dan metode Isohyet (Suryatmo, 2016). Metode ini aritmatik paling sederhana, pengukuran yang dilakukan di beberapa stasiun dalam waktu yang bersamaan dijumlahkan dan kemudian dibagi jumlah stasiun (Triatmodjo, 2014). Sedangkan Isohyet adalah garis yang menghubungkan titik-titik dengan kedalaman hujan yang sama. Pada metode Isohyet, dianggap bahwa hujan pada suatu daerah di antara dua garis Isohyet adalah merata dan sama dengan nilai ratarata dari kedua garis Isohyet tersebut. Metode Poligon Thiessen adalah metode dengan meperhitungkan berdasarkan rata-rata timbang (Dwirani, 2019). Masingmasing penakar mempunyai daerah pengaruh yang dibentuk dengan menggambarkan garis-garis sumbu tegak lurus terhadap garis penghubung di antara dua atau tiga buah pos penakar. Curah hujan rata-rata metode polygon thiessen menggunakan persamaan berikut:

$$
R=\frac{\sum A i \cdot R i}{A i}
$$

dimana,

$R \quad$ : curah hujan daerah $(\mathrm{mm} / \mathrm{hari})$

$A \quad$ : luas wilayah $\left(\mathrm{Km}^{2}\right)$ 


\section{METODELOGI PENELITIAN}

\subsection{Lokasi penelitian}

Penelitian ini dilakukan pada Daerah Aliran Sungai (DAS) Air Manna, Provinsi Bengkulu. Letak lokasi pengambilan data untuk sampel perhitungan yaitu pada bagian hilir DAS Air Manna yaitu pada Desa Batu Kuning yang terletak pada kordinat 3'45'31.818' Lintang Selatan dan 102 26'01.448' Peta lokasi DAS Air Manna dapat dilihat pada Gambar 3.1 dan peta lokasi penelitian dapat dilihat pada Gambar 3.1.

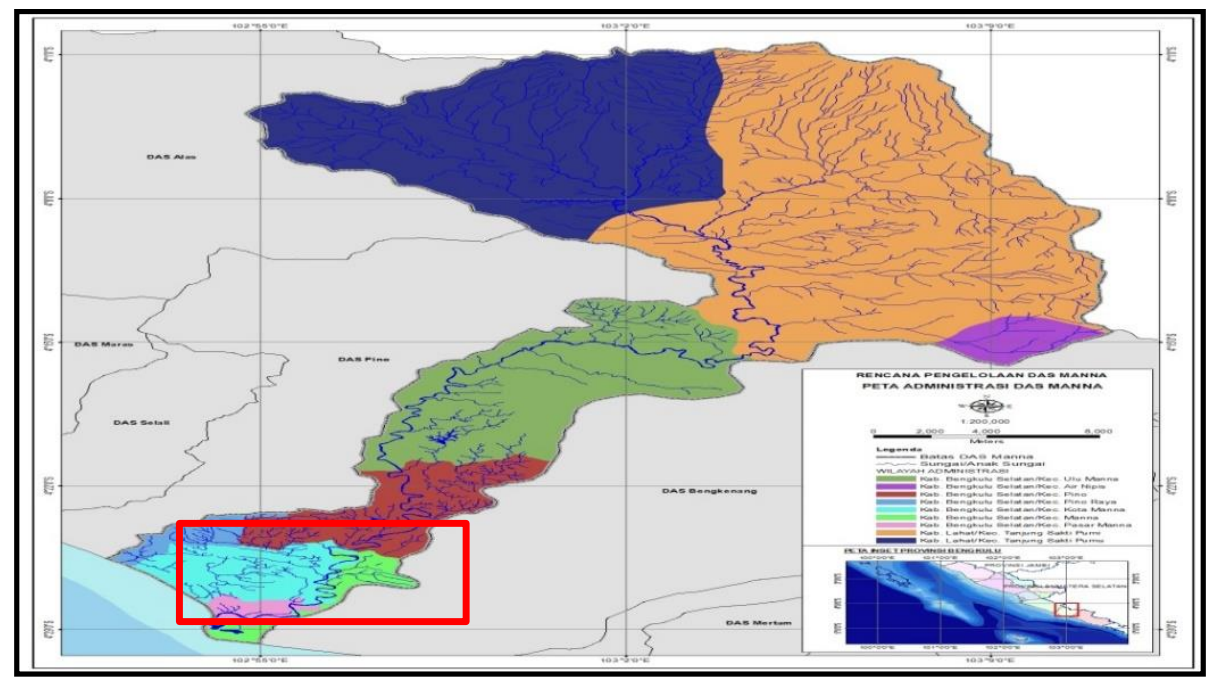

Sumber : Peta BPDAS Ketahun,2016

Gambar 3.1 Lokasi Penelitian DAS Air Manna Bagian Hilir

\subsection{Tahapan proses penelitian}

Beberapa tahapan proses dalam penelitian ini dapat diuraikan sebagai berikut:

1) Pengambilan data menggunakan current meter (Widyastuti, 2016)

- Pilih lokasi pengukuran debit dengan kriteria berada pada bagian yang lurus, titik sungai jauh dari cabang, serta sungai memiliki dasar yang stabgil, tidak ada halangan dari tumbuh-tumbuhan air, serta aliran tidak melimpah melewati tebing sungai.

- Tentukan arah penampang melintang, harus tegak lurus arah aliran.

- Tanggal pengukuran, nama sungai, lokasi pengukuran (koordinat dan administratif), nomor current meter, persamaan current meter yang digunakan dan sketsa pengukuran dicatat.

- Lebar permukaan air sungai diukur kemudian temukan interval seksi (tidak boleh lebih besar dari 1/20 total lebar), pengukuran dibagi segmen-segmen (horizontal) 1,2 3, dst dengan jarak tertentu, dan pengukuran kecepatan arus vertikal dapat diukur dengan metode 1 atau 2 titik tergantung kedalaman segmen.

- Current meter (Pastikan baling berputar dan bunyi "siren horn") disiapkan kemudian pengecekan dilakukan untuk mengetahui apakah alat terhubung dengan odometer sebagai pencatat jumlah putaran.

- Stopwatch disiapkan untuk mengetahui waktu pengukuran. 
- Saat mulai pengukuran selalu dicatat waktu/jam, tinggi muka air (baca staff gauge), pengukuran dimulai dapat di mulai dari tepi kanan atau kiri sungai..

- Jarak dari tepi air (titik nol) diukur sampai dititik seksi tempat pengukuran kecepatan aliran

- Kedalaman air diukur dengan menggunakan peilschaal.

2) Perhitungan Debit Banjir Rencana

- Mengumpulkan data yang diperlukan dalam perhitungan.

- Perhitungan curah hujan harian maksimum rerata untuk tiap-tiap tahun data dengan metode Partial Series.

- Menentukan parameter statistik dari data yang telah diurutkan dari kecil kebesar, yaitu Nilai rata-rata (X), Deviasi standar (Sd), Koefisien kemencengan (Cs), Koefisien Kurtosis (Ck), dan Koefisien variasi (Cv).

- Analisis curah hujan rencana dicoba dengan menggunakan distribusi, yaitu distribusi Gumbel Tipe I, Log Pearson Tipe III, dan Log Normal. Rumus umum yang digunakan $\mathrm{X}_{\mathrm{t}}=\overline{\mathrm{X}}+\mathrm{Kt} \times \mathrm{S}$.

- Uji kecocokan sebaran menggunakan Chi-Kuadrat dan SmirnovKolmogorov, dengan kriteria pengujian:

Untuk Uji Chi-Kuadrat jika nilai $\mathrm{f}^{2}$ Hitungan $<\mathrm{F}^{2}$ cr (diterima).

Untuk Uji Smirnov-Kolmogorov jika nilai Dmaks < Do kritis (diterima).

- Analisis intensitas curah hujan dihubungkan dengan kejadian dan lamanya curah hujan, rumus yang digunakan adalah rumus Dr. Mononobe. Rumus dapat dilihat pada Persamaan 2.14.

- Menganalisis debit aliran dasar (base flow)

- Menentukan curah hujan efektif jam-jaman.

- Analisis Hidrograf Satuan dengan Metode Snyder.

- Menentukan besarnya debit puncak (Qp) dengan periode ulang 2, 5, 10 dan 25 tahun.

3) Input Data ke HEC-RAS

4) Analisis Kapasitas Tampungan

Setelah semua data yang dibutuhkan diolah menggunakan rumus yang telah ditetapkan, data-data yang diperoleh dimasukan kedalam program dan disesuaikan dengan keadaan/kondisi dari DAS Air Manna. Langkah selanjutnya ialah melakukan running program pada aplikasi HEC-RAS yang menghasilkan output yaitu berupa profil muka air dan kapasitas tampungan sungai.

\subsection{Bagan Alir}

Bagan alir pada penelitian ini bertujuan untuk menggambarkan tahapantahapan dalam melaksanakan penelitian dari awal hingga selesai. Berikut bagan alir penelitian yang dilakukan: 


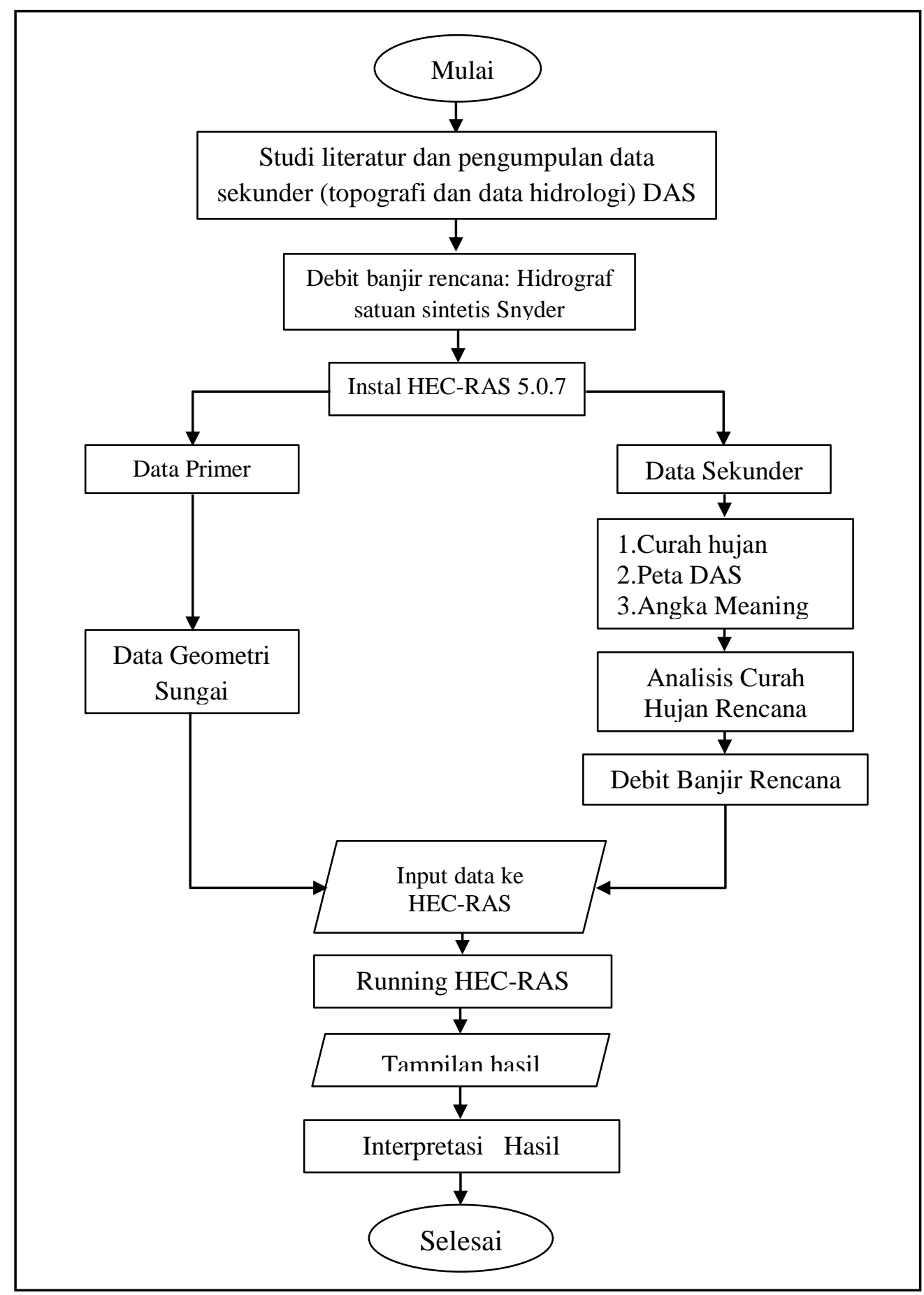

Gambar 3.2 Diagram Alir Pelaksanaan Peneliti

\section{ANALISIS DAN PEMBAHASAN}

\subsection{Analisis Debit Sungai di Lapangan}

Berdasarkan penelitian yang dilakukan pada DAS Air Manna Bagian Hilir telah didapat data-data lapangan yaitu berupa lebar, kedalaman, kecepatan, serta luas. Semua data yang didapat akan digunakan untuk menghitung debit lapangan. Penelitian ini menggunakan alat current meter sebagai alat ukur kecepatan yang dilakukan dengan metode merawas. 
Berdasarkan pengukuran di lapangan bahwa jumlah kecepatan aliran dari hasil pengukuran di lapangan dapar dilihat pada Lampiran I yaitu 1,194 m/dtk untuk luasnya adalah $53,36 \mathrm{~m}^{2}$ sehingga menghasilkan debit aliran sebesar 63,725 $\mathrm{m}^{3} / \mathrm{dtk}$. Dari Lampiran II dapat diketahui berdasarkan pengukuran di lapangan bahwa jumlah kecepatan aliran dari hasil pengukuran di lapangan yaitu 1.130 $\mathrm{m} / \mathrm{dtk}$ untuk luasnya adalah $31,12 \mathrm{~m}^{2}$ sehingga menghasilkan debit aliran sebesar $35,152 \mathrm{~m}^{3} / \mathrm{dtk}$.

Hasil pengukuran di lapangan yang didapat hanya luasan kecil dalam $\mathrm{m}^{2}$, sehingga dari hasil perhitungan debit yang dihasilkan pun kecil. Hasil pada metode hidrograf ini dalam proses perhitungannya membutuhkan curah hujan 10 tahun terakhir. Data-data seperti curah hujan tersebut tidak dibutuhkan pada pengukuran di lapangan, sehingga debit yang diperoleh masing-masing pun wajar terlalu jauh selisihnya. Sehingga pengukuran di lapangan dan perhitungan menggunakan metode hidrograf tidak bisa dibandingkan disebabkan parameterparameter, data yang diperlukan dan metode yang digunakan berbeda.

\subsection{Analisis Curah Hujan}

Data curah hujan harian pada penelitian ini menggunakan data Sta. Batu Bandung, Sta. Selali dan Sta. Manna. Data curah hujan yang ada kemudian dianalisis untuk mendapatkan data curah hujan maksimum. Analisis curah hujan maksimum didapat dengan mengambil rata-rata dari ketiga pos curah hujan, dilakukan analisis dengan metode partial series (mengurutkan data dari kecil ke besar atau sebaliknya). Berdasarkan analisa diperoleh curah hujan harian maksimum rata-rata tertinggi pada DAS Air Manna bagian Hilir di Pos Hujan Manna, Pos Hujan Selali dan Pos Hujan Batu Bandung pada tahun 2014 sebesar $658,67 \mathrm{~mm}$ dan curah hujan bulanan minimum pada tahun 2017 dengan nilai 448,53 mm. Data stasiun hujan pada penelitian ini kemudian dibuat pemodelan Poligon Thiessen, untuk mendapatkan pembagian luasan DAS. Luasan poligon penyusun DAS dengan presentase luasan disajikan pada Tabel 4.1.

Tabel 4.1 Bobot Luasan Poligon Thiessen

\begin{tabular}{|c|c|c|c|}
\hline No. & Stasiun Hujan & Bobot Luasan $\left(\mathbf{k m}^{2}\right)$ & Bobot Luasan (\%) \\
\hline 1 & Batu Bandung & 39.17 & 44.51 \\
\hline 2 & Selali & 21.98 & 24.98 \\
\hline 3 & Manna & 26.85 & 30.51 \\
\hline \multicolumn{2}{|c|}{ Total Luasan DAS } & 88 & 100 \\
\hline
\end{tabular}

Sumber: Hasil Pengolahan, 2020.

Curah hujan maksimum dan luasan thiessen yang telah diperoleh selanjutnya digunakan untuk menganalisa Rthiessen. Hasil analisa Rthiessen tahun 2010 - 2019 disajikan pada Tabel 4.2.

Tabel 4.2 Rekap Data Hujan Hasil Analisa Poligon Thiessen

\begin{tabular}{|c|c|c|c|c|}
\hline \multirow{2}{*}{ Tahun } & \multicolumn{3}{|c|}{ Rh Max Stasiun (mm) } & Rh $_{\text {Thiessen }}$ \\
\cline { 2 - 5 } & Manna & Selali & Batu Bandung & $(\mathbf{m m})$ \\
\hline 2010 & 457,00 & 403,00 & 599,00 & 506,718 \\
\hline
\end{tabular}




\begin{tabular}{|c|c|c|c|c|}
\hline 2011 & 521,00 & 328,00 & 562,00 & 491,044 \\
\hline 2012 & 613,00 & 655,00 & 519,00 & 581,650 \\
\hline 2013 & 671,00 & 558,00 & 552,00 & 589,807 \\
\hline 2014 & 729,00 & 628,00 & 619,00 & 654,810 \\
\hline 2015 & 489,00 & 667,00 & 392,00 & 490,284 \\
\hline 2016 & 513,00 & 526,00 & 423,00 & 476,187 \\
\hline 2017 & 569,00 & 489,00 & 287,58 & 423,753 \\
\hline 2018 & 934,00 & 396,00 & 394,17 & 559,336 \\
\hline 2019 & 733,00 & 485,00 & 365,52 & 507,487 \\
\hline Rata-Rata & 622,9 & 513,5 & 471,33 & 528,108 \\
\hline
\end{tabular}

Sumber:Hasil Pengolahan, 2020

Setelah dilakukan analisis data curah hujan rerata tahunan tiap pos hujan menggunakan metode Thiessen, selanjutnya dilakukan analisis dengan metode partial series, yaitu mengurutkan data dari kecil ke besar atau sebaliknya. Data curah hujan tahunan rerata yang sudah diurutkan dapat dilihat pada Tabel 4.3.

Tabel 4.3 Urutan Data Curah Hujan Rerata Tahunan dari Kecil Terbesar

\begin{tabular}{|c|c|c|}
\hline NO. & TAHUN & DATA $(\mathbf{X})$ \\
\hline 1. & 2017 & 423,753 \\
\hline 2. & 2016 & 476,187 \\
\hline 3. & 2015 & 490,284 \\
\hline 4. & 2011 & 491,044 \\
\hline 5. & 2010 & 506,718 \\
\hline 6. & 2019 & 507,487 \\
\hline 7. & 2018 & 559,336 \\
\hline 8. & 2012 & 581,650 \\
\hline 9. & 2013 & 589,807 \\
\hline 10. & 2014 & 654,810 \\
\hline
\end{tabular}

Sumber: Hasil Pengolahan, 2020.

Berdasarkan hasil perhitungan pada Tabel 4.3 diperoleh bahwa curah hujan rerata tahunan tertinggi pada DAS Air Manna Bagian Hilir di tiga pos hujan yang sudah diurutkan mengalami curah hujan harian maksimum yaitu pada tahun 2014 sebesar $654,810 \mathrm{~mm}$ dan curah hujan rerata tahunan minimum terjadi pada tahun 2017 dengan nilai 423,753 mm.

\subsection{Analisis Frekuensi Curah Hujan Rencana}

\subsubsection{Parameter Statistik (Pengukuran Dispersi)}

Perhitungan parameter statistik dapat diuraikan sebagai berikut:

a. Rata-rata:

$$
\bar{X}=\frac{\sum_{i=1}^{n} X i}{n}=\frac{5281,08}{10}=528,11
$$

b. Deviasi standar 


$$
S d=\sqrt{\frac{\sum_{i=1}^{n}\left(X_{i}-\bar{X}\right)^{2}}{n-1}}=\sqrt{\frac{40975.13}{10-1}}=67,47
$$

c. Koefisien kemencengan (Skewness)

$$
\begin{aligned}
C s & =\frac{n \sum_{i=1}^{n}\left\{\left(X_{i}\right)-\bar{X}\right\}^{3}}{(n-1)(n-2) S d^{3}} \\
& =\frac{1052910,43 \times 10}{(10-1)(10-2) \times 67,47^{3}}=0,48
\end{aligned}
$$

d. Koefisien kurtosis

$$
\begin{aligned}
C k & =\frac{\frac{1}{\mathrm{n}} \sum_{\mathrm{i}=1}^{\mathrm{n}}\left\{\left(\mathrm{X}_{\mathrm{i}}\right)-\overline{\mathrm{X}}\right\}^{4}}{\mathrm{Sd}^{4}} \\
& =\frac{\frac{1}{10} \times 411559552,35}{67,47^{4}}=1,99
\end{aligned}
$$

e. Koefisien variasi

$$
C v=\frac{S d}{\bar{X}}=\frac{67,47}{528,11}=0,128
$$

Berdasarkan perhitungan diatas dapat diketahui nilai parameter statistik yang selanjutnya akan digunakan untuk penentuan pemilihan jenis distribusi. Nilai statistik dan logaritmik ditabelkan ke tabel 4.4.

Tabel 4.4 Hasil Perhitungan Dispersi

\begin{tabular}{|c|c|}
\hline Parameter Statistik & Nilai \\
\hline Rata-rata & 528,11 \\
\hline Standar Deviasi & 67,47 \\
\hline Koefisien Kemencengen (Cs) & 0,48 \\
\hline Koefisien Kurtosis (Ck) & 1,99 \\
\hline Koefisien Variasi (Cv) & 0,128 \\
\hline Sumber: Hasil Perhitungan, 2020
\end{tabular}

\subsubsection{Analisis Jenis Distribusi}

Analisa jenis distribusi dilakukan dengan tiga metode yaitu metode gumbel tipe I, Metode Log Pearson Tipe III dan metode log normal. Hasil perhitungan curah hujan rencana dengan ketiga metode tersebut dapat ditunjukkan pada Tabel 4.6.

Tabel 4.6 Rekapitulasi Curah Hujan Rencana

\begin{tabular}{|c|c|c|c|c|}
\hline No. & Periode & Gumbel Tipe I & Log Normal & Log Pearson III \\
\hline 1 & 2 & 518,963 & 513,263 & 522,185 \\
\hline
\end{tabular}


Doi : https://doi.org/10.51988/jtsc.v2i2.32

\begin{tabular}{|c|c|c|c|c|}
\cline { 3 - 5 } 2 & 5 & 599,497 & 571,291 & 582,307 \\
\hline 3 & 10 & 652,810 & 613,125 & 617,956 \\
\hline 4 & 25 & 720,192 & 669,804 & 659,612 \\
\hline 5 & 50 & 770,173 & 713,662 & 688,496 \\
\hline 6 & 100 & 812,678 & 760,894 & 716,196 \\
\hline
\end{tabular}

Sumber: Hasil Perhitungan, 2020

Tabel 4.7 menunjukan beberapa parameter yang menjadi syarat penggunaan suatu metode distribusi. Dari Tabel tersebut ditunjukkan beberapa nilai Cs dan $\mathrm{Ck}$ yang menjadi persyaratan dari penggunaan tiga jenis metode distribusi.

Tabel 4.7 Syarat Penggunaan Jenis Sebaran

\begin{tabular}{|c|c|c|l|c|}
\hline No & Jenis Distribusi & Syarat & $\begin{array}{c}\text { Hasil } \\
\text { Perhitungan }\end{array}$ & Keterangan \\
\hline \multirow{2}{*}{1} & $\begin{array}{c}\text { Metode Gumbel } \\
\text { Tipe I }\end{array}$ & $\mathrm{Ck} \approx 5,4$ & $\mathrm{Ck}=1,99$ & $\begin{array}{c}\text { Tidak } \\
\text { Memenuhi }\end{array}$ \\
\cline { 3 - 5 } & & $\mathrm{Cs} \approx 1,14$ & $\mathrm{Cs}=0,48$ & $\begin{array}{c}\text { Tidak } \\
\text { Memenuhi }\end{array}$ \\
\hline & $\begin{array}{c}\text { Metode Log } \\
\text { Normal }\end{array}$ & $\mathrm{Cs}=\mathrm{Cv} 3+3 \mathrm{Cv}=2$ & $\mathrm{Cs}=0,48$ & $\begin{array}{c}\text { Tidak } \\
\text { Memenuhi }\end{array}$ \\
\cline { 3 - 5 } & & $\mathrm{Ck}=\mathrm{Cv} 8+6 \mathrm{Cv} 6+15 \mathrm{Cv} 4+16 \mathrm{Cv} 2+3$ \\
$=10,11$ & $\mathrm{Ck}=1,99$ & $\begin{array}{c}\text { Tidak } \\
\text { Memenuhi }\end{array}$ \\
\hline 3 & $\begin{array}{c}\text { Metode Log } \\
\text { Pearson Tipe III }\end{array}$ & Selain nilai di atas & $\mathrm{Ck}=1,99$ & Memenuhi \\
\hline
\end{tabular}

Sumber: Hasil Perhitungan, 2020

Dari ketiga metode yang akan digunakan diatas yang paling mendekati adalah sebaran dengan menggunakan jenis Metode Log Pearson Tipe III dengan nilai $\mathrm{Ck}=1,95$. Dari jenis sebaran yang telah memenuhi syarat tersebut perlu diuji kecocokan sebarannya dengan beberapa metode. Hasil uji kecocokan sebaran menunjukkan distribusinya dapat diterima atau tidak.

\subsubsection{Pengujian Kecocokan Sebaran}

Pengujian kecocokan sebaran dilakukan dengan Uji Kecocokan ChiKuadrat (Chi-Square) dan Uji kecocokan Smirnov-Kolmogorov. Untuk menguji kecocokan sebaran Metode Log Pearson Tipe III, digunakan uji kecocokan sebaran Chi-Kuadrat (Chi-Square) (Soewarno, 1995). Hasil perhitungan akan menunjukkan Nilai $\mathrm{X}^{2} \mathrm{Cr}$ yang didapat dengan cara melihat nilai DK dihubungkan pada derajat kepercayaan $(\alpha)$. Dilihat hasil perbandingan pada penelitian ini bahwa ternyata $X^{2}$ Hitungan $(6,00)<X^{2} \mathrm{Cr}(7,815)$, maka hipotesa yang diuji dapat diterima.

Sedangkan Uji kecocokan Smirnov-Kolmogorov, sering juga uji kecocokan non parametrik (nonparametric test), tidak menggunakan fungsi distribusi tertentu. Hasil perhitungan akan menunjukkan Nilai Do kritis yang 
didapat dengan cara melihat jumlah data (n) dihubungkan pada derajat kepercayaan $(\alpha)$. Dilihat dari perbandingan di atas bahwa $\mathrm{D}_{\text {maks }}(0.20)<\mathrm{D} 0_{\text {kritis }}$ (0.41), maka metode sebaran yang diuji dapat diterima.

\subsection{Analisis Intensitas Curah Hujan (It)}

Perhitungan intensitas curah hujan ini menggunakan metobe Dr. Mononobe yang merupakan sebuah variasi dari persamaan-persamaan curah hujan jangka pendek. Dari metode Mononobe dapat digambarkan ke dalam kurva IDF dengan metode Mononobe seperti terlihat pada Gambar 4.5.

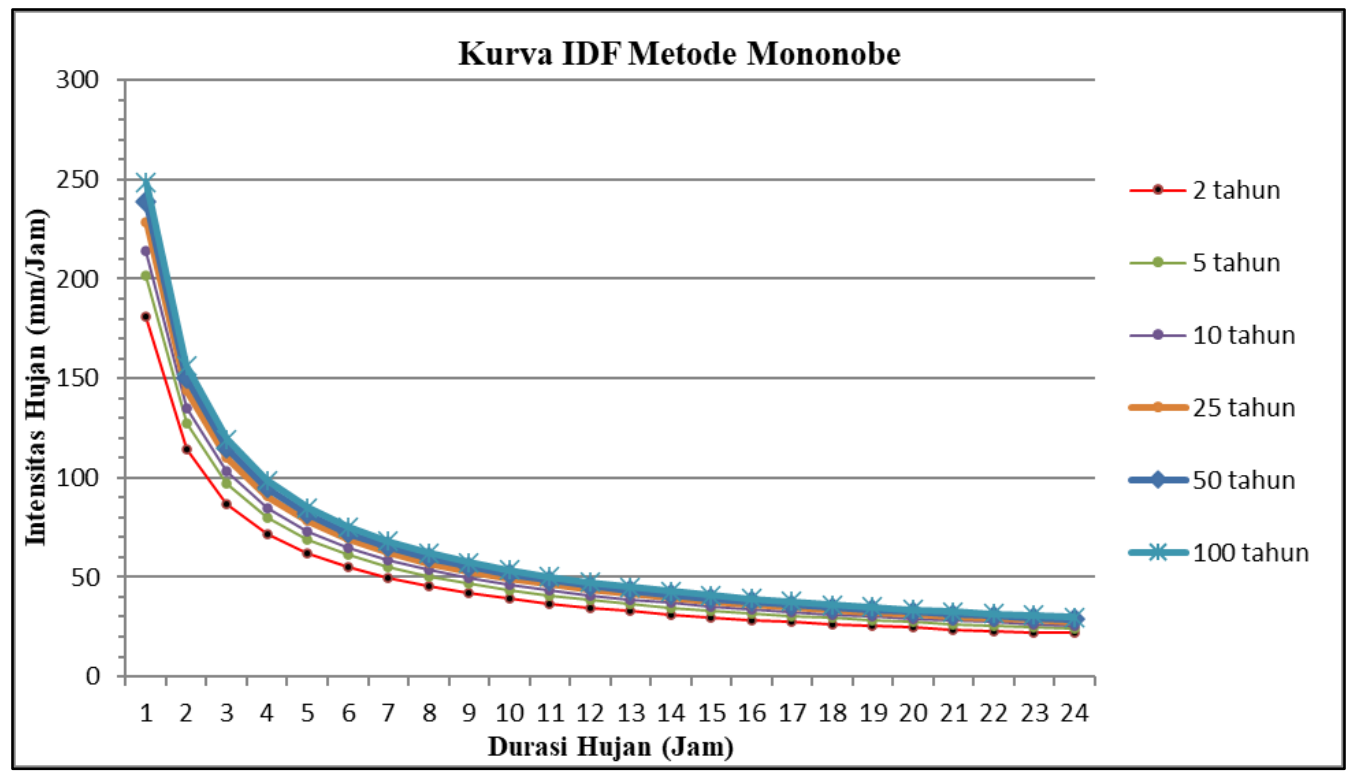

Gambar 4.1 Kurva IDF dengan Metode Mononobe

\subsubsection{Curah Hujan Jam-jaman}

Distribusi hujan yang sering terjadi di Indonesia dengan hujan terpusat 1 hingga 6 jam. Perhitungan rasio hujan jam-jaman, distribusi hujan jam-jaman dari hujan terpusat selama 6 jam dapat dilihat pada Tabel 4.8 .

Tabel 4.8 Perhitungan Rasio Hujan Jam-jaman

\begin{tabular}{|c|c|c|c|c|c|c|}
\hline $\begin{array}{c}\text { Jam Ke- } \\
(\mathbf{T})\end{array}$ & \multicolumn{2}{|c|}{$\begin{array}{c}\text { Distribusi Hujan } \\
(\mathbf{R t})\end{array}$} & \multicolumn{2}{c|}{$\begin{array}{c}\text { Curah Hujan } \\
\text { Jam Ke- }\end{array}$} & Rasio (\%) & Komulatif (\%) \\
\hline 1 & 0.55 & R24 & 0.55 & R24 & 55.032 & 55.032 \\
\hline 2 & 0.143 & R25 & 0.143 & R25 & 14.304 & 69.336 \\
\hline 3 & 0.1 & R26 & 0.1 & R26 & 10.034 & 79.37 \\
\hline 4 & 0.08 & R27 & 0.08 & R27 & 7.988 & 87.358 \\
\hline 5 & 0.067 & R28 & 0.067 & R28 & 6.746 & 94.104 \\
\hline
\end{tabular}




\begin{tabular}{|c|c|c|c|c|c|c|}
\hline 6 & 0.059 & R29 & 0.059 & R29 & 5.896 & 100 \\
\hline
\end{tabular}

Sumber : Hasil Perhitungan, 2020.

Analisa curah hujan efektif adalah bagian hujan yang menghasilkan limpasan langsung. Dengan asumsi bahwa proses transformasi hujan menjadi limpasan langsung mengikuti proses linier dan tidak berubah oleh waktu. Hasil perhitungan untuk curah hujan efektif dapat dilihat pada Tabel 4.20.

Tabel 4.9 Perhitungan Rasio Jam-jaman.

\begin{tabular}{|c|c|c|c|c|c|c|c|}
\hline Jam ke & Rasio & $\mathbf{2}$ & $\mathbf{5}$ & $\mathbf{1 0}$ & $\mathbf{2 5}$ & $\mathbf{5 0}$ & $\mathbf{1 0 0}$ \\
\hline 1 & 0.55 & 71.800 & 80.067 & 84.969 & 90.697 & 94.668 & 98.476 \\
\hline 2 & 0.143 & 18.668 & 20.817 & 22.092 & 23.581 & 24.613 & 25.603 \\
\hline 3 & 0.1 & 13.055 & 14.558 & 15.449 & 16.490 & 17.212 & 17.904 \\
\hline 4 & 0.08 & 10.444 & 11.646 & 12.359 & 13.192 & 13.769 & 14.323 \\
\hline 5 & 0.067 & 8.747 & 9.754 & 10.351 & 11.048 & 11.532 & 11.996 \\
\hline 6 & 0.059 & 7.702 & 8.589 & 9.115 & 9.729 & 10.155 & 10.563 \\
\hline \multicolumn{2}{|c|}{ hujan rancangan } & 522.185 & 582.307 & 617.956 & 659.612 & 688.496 & 716.196 \\
\hline \multicolumn{2}{|c|}{$\begin{array}{c}\text { koeefesien } \\
\text { pengaliran }\end{array}$} & 0.25 & 0.25 & 0.25 & 0.25 & 0.25 & 0.25 \\
\hline \multicolumn{2}{|c|}{ hujan efektif } & 130.546 & 145.577 & 154.489 & 164.903 & 172.124 & 179.049 \\
\hline
\end{tabular}

Sumber: Hasil Perhitungan, 2020

\subsection{Analisis Debit Banjir Rencana}

\subsubsection{Debit Aliran Dasar (Base Flow)}

Dengan pertimbangan bahwa lokasi studi tidak tersedia data debit pengamatan untuk mengetahui debit aliran dasar, maka perhitungan Debit Aliran Dasar (Base Flow) dapat dilakukan sebagai berikut:

Luas DAS hulu $(\mathrm{A}) \quad=88 \mathrm{~km}^{2}$

Panjang Total $\quad=27,5 \mathrm{~km}$

Panjang sungai tingkat 1 sampai tingkat 2 dapat dilihat pada Lampiran 13

Perhitungan kerapatan jaringan sungai:

$$
\begin{aligned}
D & =\frac{\text { Panjang Total Sungai }}{\text { Luas DAS }(A)} \\
& =\frac{27,5}{88}=0,3125
\end{aligned}
$$

Menghitung besar aliran dasar QB dengan menggunakan Persamaan sebagai berikut:

$$
\begin{aligned}
Q B & =0,4751 \times A^{0,6444} \times D^{0,9430} \\
& =0,4751 \times 88^{0,6444} \times 0,3125^{0,9430} \\
& =2,819 \mathrm{~m}^{3} / \text { detik }
\end{aligned}
$$

\subsubsection{Perhitungan Hidrograf Satuan Sintetis Snyder}

Persamaan umum hidrograf satuan sintetis Snyder adalah sebagai berikut :

$$
Q_{p}=\frac{0,275 \times C_{p} \times A}{T_{p}}
$$


Tabel 4.10 Rekapitulasi Hidrograf Banjir Snyder

\begin{tabular}{|c|c|c|c|c|c|c|}
\hline \multirow{3}{*}{$\begin{array}{c}\text { Waktu (t) } \\
(\text { jam) }\end{array}$} & \multicolumn{6}{|c|}{ Periode Ulang (Tahun) } \\
\hline & Q2 & Q5 & Q10 & Q25 & Q50 & Q100 \\
\hline & m3/detik & m3/detik & m3/detik & m3/detik & m3/detik & m3/detik \\
\hline 0 & 2,819 & 2,819 & 2,819 & 2,819 & 2,819 & 2,819 \\
\hline 1 & 91,786 & 102,661 & 109,627 & 116,626 & 121,858 & 126,859 \\
\hline 2 & 577,636 & 648,892 & 693,216 & 740,397 & 774,677 & 807,444 \\
\hline 3 & 981,305 & 1104,083 & 1179,634 & 1261,754 & 1320,821 & 1377,281 \\
\hline 3,5 & 1180,958 & 1330,425 & 1421,861 & 1522,369 & 1594,275 & 1663,007 \\
\hline 4 & 1308,103 & 1475,398 & 1577,357 & 1690,237 & 1770,720 & 1847,651 \\
\hline 5 & 1295,214 & 1462,456 & 1564,111 & 1677,226 & 1757,683 & 1834,590 \\
\hline 6 & 1107,872 & 1250,871 & 1337,790 & 1434,508 & 1503,303 & 1569,061 \\
\hline 7 & 918,305 & 1036,773 & 1108,782 & 1188,909 & 1245,902 & 1300,380 \\
\hline 8 & 746,431 & 842,658 & 901,148 & 966,231 & 1012,524 & 1056,774 \\
\hline 9 & 598,926 & 676,065 & 722,953 & 775,127 & 812,237 & 847,709 \\
\hline 10 & 476,299 & 537,569 & 574,812 & 616,252 & 645,728 & 673,904 \\
\hline 11 & 376,386 & 424,727 & 454,111 & 486,806 & 510,063 & 532,292 \\
\hline 12 & 296,079 & 334,028 & 357,095 & 382,762 & 401,019 & 418,470 \\
\hline 13 & 232,148 & 261,824 & 279,862 & 299,933 & 314,210 & 327,857 \\
\hline 14 & 181,610 & 204,746 & 218,809 & 234,457 & 245,588 & 256,227 \\
\hline 15 & 141,870 & 159,864 & 170,802 & 182,972 & 191,628 & 199,903 \\
\hline 16 & 110,751 & 124,718 & 133,207 & 142,654 & 149,373 & 155,796 \\
\hline 17 & 86,460 & 97,283 & 103,862 & 111,182 & 116,389 & 121,367 \\
\hline 18 & 67,548 & 75,924 & 81,015 & 86,680 & 90,710 & 94,562 \\
\hline 19 & 52,855 & 59,330 & 63,265 & 67,644 & 70,759 & 73,737 \\
\hline 20 & 41,460 & 46,460 & 49,499 & 52,881 & 55,287 & 57,586 \\
\hline 21 & 32,635 & 36,493 & 38,838 & 41,448 & 43,304 & 45,078 \\
\hline 22 & 25,809 & 28,784 & 30,592 & 32,604 & 34,035 & 35,404 \\
\hline 23 & 20,535 & 22,827 & 24,221 & 25,771 & 26,874 & 27,928 \\
\hline 23 & 20,535 & 22,827 & 24,221 & 25,771 & 26,874 & 27,928 \\
\hline
\end{tabular}

Sumber: Hasil Perhitungan, 2020

Dari hasil rekapitulasi hidrograf banjir rencana pada Tabel 4.10 dari periode ulang 2 tahun sampai 100 tahun, dibuat grafik hidrograf banjir untuk Sub DAS Rindu Hati dengan menggunakan metode Hidrograf Satuan Sintetis Snyder. Pada periode ulang 2 tahun debit puncaknya sebesar $83,44 \mathrm{~m}^{3} /$ detik dan debit puncak pada periode 100 tahun nilainya sebesar $1322,217 \mathrm{~m}^{3} /$ detik.

\subsection{Analisis Hidrolika dengan $H E C-R A S$ 5.0.7}

Analisa didahului dengan Membuat Peta Sub DAS Air Manna Bagian Hilir di HEC-RAS 5.0.7. Peta digunakan untuk memudahkan dalam menggambar alur sungai, sehingga didapatkan hasil yang skalatis dan sesuai dengan keadaan aslinya. 


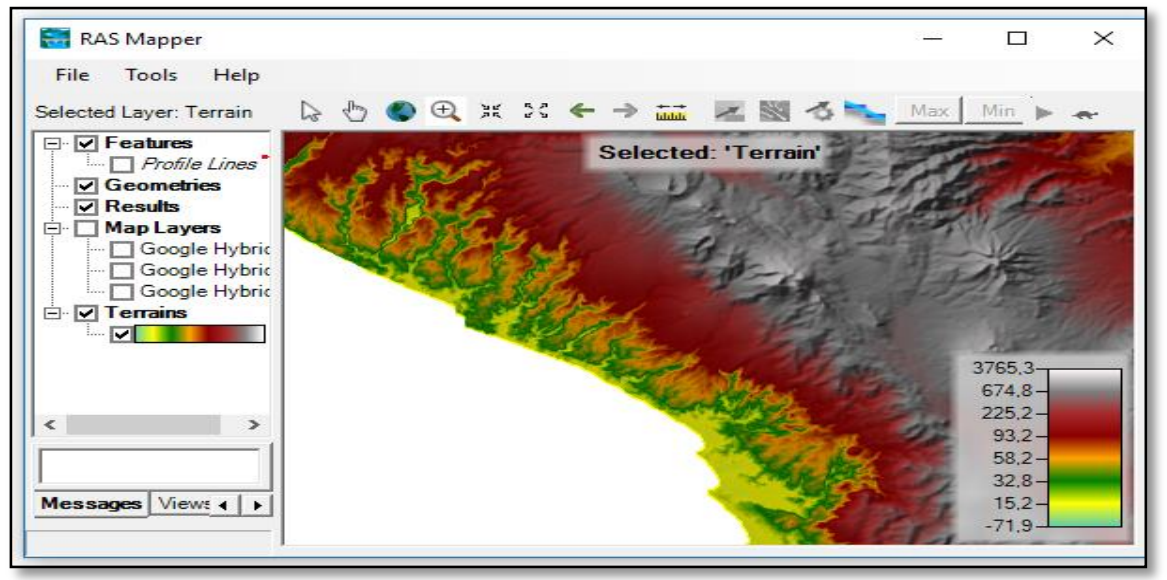

Gambar 4.6 Peta Terrain Wilayah Bengkulu

Selanjutnya adalah Memasukan Data Geomteri Sungai pada HEC-RAS 5.0.7. Sungai Air Manna merupakan aliran tak permanen atau aliran unsteady maka untuk memasukan data debit rencana menggunakan menu Unsteady Flow Data. Setelah dilakukan running program HEC-RAS atau menginterpolasikan penampang sungai terlebih dahulu, ada penampang sungai dibeberapa stationing tidak dapat menampung debit banjir. Potongan melintang Sungai Air Manna dengan simulasi debit banjir rencana periode 2 tahun dan periode 100 tahun. Analisis penampang eksisting dengan menggunakan HEC-RAS bertujuan untuk mengetahui kondisi dari Sungai Air Manna saat ini (eksisting). Dengan menggunakan HEC-RAS maka dapat diketahui profil dari muka air saat terjadi banjir. HEC-RAS akan menampilkan model dari Sungai Air Manna sesuai dengan input data yang diberikan, untuk membuat model aliran Sungai.

\section{KESIMPULAN}

Berdasarkan keseluruhan hasil analisa data yang dilakukan dalam penyusunan skripsi ini dapat ditarik beberapa kesimpulan sebagai berikut :

1. Hasil analisa hidrologi menggunakan metode Snyder pada DAS Air Manna Bagian Hilir dengan mengabaikan perubahan tata guna lahan didapat nilai debit:

$\mathrm{Q}_{2 \text { th }}=1182,642 \mathrm{~m}^{3} /$ detik

$\mathrm{Q}_{5 \text { th }} \quad=1332,322 \mathrm{~m}^{3} /$ detik

$\mathrm{Q}_{10 \mathrm{th}}=1423,889 \mathrm{~m}^{3} /$ detik

$\mathrm{Q}_{25 \mathrm{th}}=1524,540 \mathrm{~m}^{3} /$ detik

$\mathrm{Q}_{50 \mathrm{th}}=1596,549 \mathrm{~m}^{3} /$ detik

$\mathrm{Q}_{100 \text { th }}=1665,379 \mathrm{~m}^{3} /$ detik

Dari hasil tersebut, debit terkecil adalah $\mathrm{Q}_{2 \mathrm{th}}=1182,642 \mathrm{~m}^{3} /$ detik dan debit terbesar adalah $\mathrm{Q}_{100 \mathrm{th}}=1665,379 \mathrm{~m}^{3} /$ detik.

2. Hasil analisis dengan menggunakan program HEC-RAS 5.0.7 dengan debit yang telah dihitung dari hasil hidrologi $\mathrm{Q}_{2 \text { th }}$ di Sungai Air Manna sebesar $1182,642 \mathrm{~m}^{3} /$ detik sudah tidak mampu menampung debit banjir. Sehingga 
diperlukan upaya perbaikan untuk mengendalikan luapan Sub DAS Air Manna Bagian Hilir.

3. Hasil analisis dengan menggunakan program HEC-RAS 5.0.7 dengan debit yang telah dihitung menghasilkan daerah potensi banjir hampir di seluruh STA dari hulu sampai bagian hilir.

\section{DAFTAR PUSTAKA}

Achmad, M. 2011. Hidrologi Teknik. Makassar: Universitas Hasanudin, Makassar.

Asdak, C. 2014. Hidrologi dan Pengelolaan Daerah Aliran Sungai. Yogyakarta: Gajah Mada University Press.

Coppola, \& Damon, P. 2007. Introduction to International Disaster Management. England, UK: Elsevier, Oxford.

Dwirani, F. 2019. Menentukan Stasiun Hujan dan Curah Hujan dengan Metode Polygon Thiessen Daerah Kabupaten Lebak. Universitas Banten Jaya. 2(2):139-146.

Retnowati, D., Lasminto, U., \& Savitri, Y. R. 2015. Studi Pengendalian Banjir dan Genangan pada Sistem Drainase Kali Puncang Sidoarjo. Studi Pengendalian Banjir dan Genangan, 22-29.

Sasrodarsono, S., \& Takeda, K. 2006. Hidrologi Untuk Pengairan. Jakarta: PT. Pradnya Paramita, Jakarta

Suryatmo, I. S. 2016. Pemodelan Luapan Banjir Sungai Air Bengkulu Menggunakan HEC-GeoRAS. Bengkulu: Fakultas Teknik Universitas Bengkulu.

Triatmodjo, B. 2014. Hidrologi Terapan. Edisi cetakan ke-4. Beta Offset. Yogyakarta.

Wigati, R., Soedarsono, \& Mutia, T. 2016. Analisis Banjir Menggunakan Software HEC-RAS 4.0.1 (Studi Kasus Sub-DAS Ciberang HM O+OO - HM 34+00). Jurnal Fondasi, 5(2), 35-42.

Widyastuti, M., Cahyadi, A. dan Sasongko, M.H.D. 2016. Pedoman Praktis Survei Terintegrasi Kawasan Karst. Yogyakarta: Badan Penerbit Fakultas Geografi (BPFG) Universitas Gadjah Mada. Halaman: 20-43. 